\title{
Spiritually-Oriented Cognitive-Behavioral Family Therapy
}

\author{
Tuğba Turgut ${ }^{1}$ \\ Fatih Sultan Mehmet Vakıf University
}

\author{
Füsun Ekşi ${ }^{2}$ \\ İstanbul Medeniyet University
}

${ }^{1}$ Research Assistant, Department of Educational Sciences, Guidance and Psychological Counseling, Fatih Sultan Mehmet Vakıf University, Istanbul, Turkey. E-mail: tturgut@fsm.edu.tr

2 Assoc. Prof., Faculty of Education Sciences, Department of Psychological Counseling and Guidance, Istanbul Medeniyet University, İstanbul, Turkey. E-mail: eksifusun@gmail.com

\begin{abstract}
A great many factors influence human life. Among these are individuals' religious and spiritual orientations, whose importance cannot be understated as they not only aff ect how individuals perceive and interpret themselves, events in their everyday lives, and the greater world but also shape their thoughts, feelings, and behaviors. Consequently, religious and spiritual orientations constitute an integral part of clients' lives and are an important element that needs to be thoroughly investigated. In addition to having been integrated into individual psychological counseling approaches, religious/ spiritual orientation has become as a highly supportive element in family therapy. Spiritually-oriented applications are quite helpful when addressing problems dealt with by individuals and families. In the current study, spiritually-oriented cognitive-behavioral family therapy is addressed in light of the relevant literature. We first present a general overview of cognitive-behavioral therapy and cognitivebehavioral family therapy, after which we frame the assessment steps followed in spiritually-oriented cognitive-behavioral family therapy within a paradigm based on religion and spirituality. After that, we reveal the religious/spiritual-based cognitive-behavioral applications that may be used during family therapy. We then discuss several exercises and applications employed during spirituallyoriented cognitive-behavioral family therapy. Finally, this study seeks to fill in gaps in the relevant literature on this topic in Turkey and off er a novel perspective to practitioners and researchers. Keywords: Spirituality $\bullet$ Family Therapy $\bullet$ Cognitive-Behavioral Therapy $\bullet$ Spiritually-Oriented Cognitive-Behavioral Family Therapy
\end{abstract}

\section{Manevi Yönelimli Bilişsel Davranış̧̧ı Aile Terapisi}

\section{Corresponding author:}

Tuğba Turgut

E-mail:

tturgut@fsm.edu.tr

eISSN: 2458-9675

Received Revision:

26.11.2019

Revision:

01.01.2020

Accepted:

11.02.2020

C) Copyright 2020

by Author(s)

\section{Öz}

İnsan yaşamında birçok faktör etkili olmakla birlikte dini ve manevi yönelim; bireylerin kendilerini, çevresindeki olayları ve dünyayı nasıl algıladığını ve anlamlandırdığını etkilemekte ayrıca bireylerin düşüncelerini, duygularını ve davranışlarını şekillendirmektedir. Bu doğrultuda dini ve manevi yönelimin danışanların önemli bir parçasını oluşturduğu, terapi sürecinde de üzerinde durulması gereken önemli bir bileșen olduğu düşünülmektedir. Dini ve manevi yönelim bireysel psikolojik danışma yaklaşımlarına entegre edilmekle birlikte, aile terapileri sürecinde de oldukça destekleyici bir unsur olarak karşımıza çıkmaktadır. Aile bireylerinde ve aile sisteminde yer alan problemleri ele alırken manevi yönelimli uygulamalar oldukça işlevsel görünmektedir. Bu doğrultuda bu çalışmada manevi yönelimli bilişsel davranışçı aile terapisinin ilgili literatür çerçevesinde ele alınması amaçlanmaktadır. Öncelikle BDT ve bilişsel davranıșçı aile terapisine genel bir bakış sunulmakta, ardından manevi yönelimli bilişsel davranışçı aile terapisi sürecinde değerlendirme aşamaları, terapinin din ve maneviyatla çerçevelendirilmesi, aile terapisi sürecinde kullanılabilecek dini-manevi temelli bilişsel davranışçı uygulamalar açıklanmakta ve son olarak manevi temelli bilişsel davranışçı aile terapisiyle ilgili gerçekleştirilen uygulamalara yer verilmektedir. Bu çalıșmanın özellikle ülkemizde eksik kalan noktaları dolduracağı, alandaki uygulayıcılara ve araştırmalara farklı bir perspektif sağlayacağı ve katkı sunacağı düşünülmektedir.

Anahtar Kelimeler: Maneviyat • Aile Terapisi • Bilişsel Davranışçı Terapi • Manevi Yönelimli Bilişsel Davranıșçı Aile Terapisi

Citation: Turgut, T., \& Ekşi, F. (2020). Spiritually-oriented cognitive-behavioral family therapy. Spiritual Psychology and Counseling, 5, 87 - 111. https://dx.doi.org/10.37898/spc.2020.5.1.095 


\section{Overview of Cognitive-Behavioral Therapy}

Cognitive-behavioral therapy (CBT) is an approach that essentially endeavors to aid individuals in reorganizing their own thought structures and both the sentences and comments employed during internal dialogue so as to instigate appropriate changes in their feelings, behaviors and, from an even wider perspective, their lives in general (Corey, 2015). Based on collaboration between counselor and client, CBT is a structured, short-term, mostly active therapy technique that emphasizes the importance of the current moment, that focuses on modifying thought structures in order to bring about change in clients' emotions and behaviors, and that generally incorporates educational characteristics (Arnkoff \& Glass, 1992; Beck \& Weishaar, 2008).

At the core of CBT is the assumption that one's cognitions (i.e., thoughts) influence his/her affectability and behaviors (Beck, 2005). Just as thoughts affect emotions and behaviors, there are mutual interactions between emotions, thoughts and behaviors. CBT holds that an individuals' affectability and behaviors are determined by the situations and events that s/he experiences and that they actually stem from how the individual perceives, relates to, and thinks about an event. Though a situation does not directly affect how an individual feels, it does mediate his/her perception of, thoughts toward, and emotional reactions to the situation, (Beck, 1995; Leahy, 2018; Sudak, 2006).

When classifications of therapies are examined, we observe that an excess of 20 different types of therapies are classified as either cognitive or cognitive-behavioral. With that, the two CBT approaches constituting the basis off of which further investigations are conducted are Ellis's Rational-Emotive Behavior Therapy and Beck's Cognitive Therapy (Corey, 2015; Murdock, 2014).

Rational-Emotive Behavior Therapy (REBT). Developed by Ellis, REBT is an approach grounded in rigorous philosophies that seeks to provoke deep-rooted changes in individuals' perspectives in which therapists play an active role and in which the educational process is integrated into therapy (Köroğlu, 2017). The basic assumption of REBT is that affectability results from individuals' current beliefs, various assessments, and their reactions to the events they face in life. Essentially, emotions, thoughts, and behaviors impact each other and depend on mutual interaction and causation (Ellis \& Dryden, 1997). At its core, REBT asserts that every human is endowed with the potential to think both rationally and rationally. Irrational beliefs are learned during childhood from people considered important to the individual (Ellis, 2001). Ellis states that underlying emotional problems are individuals' own accusations against themselves. He highlights the importance of an individual's ability to accept him/herself unconditionally and states that being able to accept oneself unconditionally is critical in resolving psychological problems (Ellis, 2007). In REBT, it is sought that non-functioning emotions and thoughts be exchanged 
with functioning mechanisms, that clients be aided in unconditionally accepting themselves and others, that the effect of destructive thoughts and beliefs causing emotional problems in the individual be reduced to a minimum, and that clients construct a rational life philosophy (Digiuseppe, Doyle, Dryden, \& Backx, 2013). A variety of techniques are utilized to realize counseling objectives, including cognitive techniques (e.g., ABC model, changing one's language, disrupting irrational beliefs), emotive techniques (e.g., rational-emotive imagery, role playing, and use of force and vigor), and behavioral techniques (e.g., systematic desensitization, relaxation exercises, and self-direction) (Corey, 2015; Dryden \& Neenan, 2006).

Cognitive Therapy (CT). Developed as a result of Beck's research on depression, $\mathrm{CT}$ is an insight-oriented approach that aims to identify and modify negative thoughts and irrational beliefs (Beck, 1979). CT is grounded in the assumptions that individuals can access their own intrapersonal communications through internal observations and that their beliefs carry meaning and importance in their lives, and that clients' beliefs and the meanings they attribute to life can be discovered through their own self-observations as opposed to counselors' interpretations (Weishaar, 1993). Seeking to understand the reason for an emotional situation, CT examines the cognitive content of an individual's reactions to the situation in question (Beck, 1995). Beck emphasizes two concepts, namely automatic thoughts and schemata, while examining individuals' cognitive content and further divides schemata into core beliefs and intermediate beliefs. Core beliefs are defined as deep mental structures containing basic assumptions formed by previous events and experiences about oneself, one's environment, and the world. The three negative core beliefs are helplessness (notions of inadequacy: "I'm incompetent", "I'm vulnerable", "I'm weak", etc.), worthlessness (notions of moral deficiency and guilt: "I don't deserve to live", "I'm worthless", etc.) and unlovability (notions of emotional deficiencies: "I'm unloved", "I'm always rejected", "I'm insignificant", etc). Encapsulating core beliefs, intermediate beliefs are general rules and underlying assumptions about life. Encompassing schemata related to both core and intermediate beliefs, automatic thoughts are general thoughts that are accepted as true without actually having scrutinized their veracity and that may appear without warning during various situations (Hofmann, 2013; Kazantzis, Dattilio, \& Dobson, 2017; Türkçapar, 2019). The main objective of therapy is to address all cognitive content and to use clients' own automatic thoughts to reach central schemata so that clients may gain an awareness of these schemata and then, by modifying their thinking styles, restructure them (Corey, 2015).

Although the majority of clients hold general assumptions like "I should be perfect", "My value is linked to others' confirmation of me", and "I should be taken seriously by everyone" in both REBT and CT, it must be remembered during in the therapeutic process that since every client will have his/her own assumptions, 
these assumptions and their relationship both with the client him/herself and others need to be examined as a whole in their own environmental context (Leahy, 2018). Moreover, since culture is an essential component that both shapes and influences how people act and what they think and feel, addressing cultural traits and how they may potentially impact therapeutic interventions is considered highly important in CBT-based therapy approaches. Seeking to ensure a culturally-sensitive therapeutic process, CBT essentially seeks to develop diverse intervention strategies that take into consideration generational influences, ethnic and racial identity, gender, sexual orientation, and spiritual/religious orientation (Bennett, Flett, \& Babbage, 2014; Hays, 2016; Wenzel, Dobson, \& Hays, 2016).

It therefore becomes necessary for religion and spirituality to be integrated into the therapeutic process during CBT-based interventions with clients for whom a religiously and spiritually oriented life is indispensably important and who expressly want religious and spiritual elements to be addressed during the therapeutic process (Pargament, 2007). Since, as a result, religious and spiritual elements are one of the components needing to be addressed during culturally sensitive therapy, they form the general framework and content focused upon in this study.

\section{Cognitive-Behavioral Family Therapy}

Before moving on to spiritually-oriented cognitive-behavioral family therapy, we believe that it would be beneficial to gain a deeper understanding of the characteristics of cognitive-behavioral family therapy (CBFT), its points of focus, and the techniques it employs.

With its recent inclusion into family therapy approaches, CBFT has, as a result of its being frequently preferred in therapy and its high effectiveness in CBT applications, emerged an important approach (Dattilio, 2018; Goldenberg \& Goldenberg, 2008; Northey, 2002). A great many researchers studying couples and family therapy have stated that integrating cognitive-behavioral techniques into their own preferred therapy paradigms has increased the effectiveness of their own therapy processes (Dattilio, 1998). While addressing CBFT, both Ellis's REBT and Beck's CT are used as bases off of which a variety of applications have been developed (Nichols, 2013).

The reason for disorders and problems in family relationships is generally a result of individuals' irrational and dysfunctional beliefs toward their partner and their negative opinions and judgments upon realization that their relationship is unable to achieve the unrealistic goals they have set. Negative cognitive structures cause individuals to experience negative emotions and adversely affect their relationships. As a consequence, the therapy process aims to help clients to be able to challenge their partner's irrational beliefs, to assess their problematic cognitions, to communicate, 
and to solve problems in a structural manner (Ellis, Sichel, Yeager, DiMattia, \& DiGiuseppe, 1989; Epstein \& Baucom, 2002).

Counselors espousing the rational-emotive approach help their clients realize that family members' irrational beliefs form the very root of emotional problems. The ABC Model essentially holds (A) that the problems faced by family members stem from specific activating events that occur within the family, (B) family members are taught how to expose irrational beliefs, and (C) that these irrational believes and thoughts are questioned. The primary objective is for family members to identify irrational beliefs and exchange them with rational, constructive beliefs and then to understand that it is irrational beliefs that cause emotional problems (Ellis, 1978; Ellis \& Dryden, 1997).

Since partners and family members interact both directly and indirectly in a causal web, the cognitive-behavioral approach agrees with systems theory. Given that family members both influence and are influenced by each other in a multitude of ways throughout their lives, it is considered essential that families be examined using systems approaches in CBFT. In order to be able to perceive a specific behavior in family relationships, it is imperative to look at individuals' communication and interaction processes together with family traits. The behaviors of one family member impact the emotions, thoughts, and behaviors of other family members within a system. It is therefore vital that systems be evaluated holistically and that appropriate methods be included in the therapeutic process (Dattilio, 2018; Nichols, 2013).

At the foundation of the systems approach are four elements related to the mutual interaction between family members' cognitions, emotions, and behaviors that are also associated with their interactions' ending in conflict. These elements are: (i) a family member distances him/herself from the rest of the family and avoids communication and interaction with other family members, (ii) family members' individual actions toward the one who has distanced him/herself, (iii) the joint reaction of some of the family members toward said individual, and (iv) common characteristics of the relationship and interactions between the other family members. The dynamics become increasingly more complicated as the number of members in a family increases (Epstein \& Schlesinger, 1996).

In Beck's CT model, certain schemata are located at the core of individuals' cognitive structures. These schemata (intermediate beliefs and core beliefs) cause individuals to hold various assumptions about the world and the events they experience (Beck, 1995; DeRubeis \& Beck, 1988). The basic objective of family therapy is to help family members expose the distorted thoughts and beliefs members so that they are able to exchange the schemata underlying their judgments and opinions they make toward each in their daily lives with positive structures (Nichols, 2013). Individuals' 
core beliefs are related to themselves, their perceptions of the world, their future orientations, and their families. Individuals generally have two schemata pertaining to family life: (i) schemata related to experiences stemming from one's family of origin and how his/her parents' parenting style and (ii) schemata related to families in general. The schemata stemming from a person's family of origin influence, either consciously or unconsciously, how s/he evaluates life experiences and the formation of schemata in his/her current family (Dattilio, 2018).

According to Dattilio (2005), the following steps occur while revealing and analyzing schemata during CBFT:

1. Identifying family schemata and uncovering what conflict situations these schemata trigger,

2. Locating the origin of family schemata and examining how these schemata became a part of the family,

3. Drawing attention to how restructuring schemata will facilitate more positive and adaptive communication in the family,

4. Eliciting an acknowledgement of the need to change dysfunctional schemata,

5. Developing strategies of change in the family,

6. Realizing change through implementation of strategies,

7. Displaying new behaviors and assessing their effectiveness, and

8. Solidifying change by establishing links between new schemata and behavior patterns.

In addition to benefiting from techniques used in CBT, CBFT is implemented in a manner integrated with the family structure. Essentially, the applications employed in this approach incorporate various behavioral techniques like educating families about the CB model, having family members recognize their distorted and negative automatic thoughts toward each other and then exchange them with positive structures, examining and restructuring initial family schemata, using imagination or role play to reframe emotions, thoughts and behaviors related to events, which are executed through diverse techniques like restructuring the negative attitudes that spouses and family members have concerning change with new ones and having family members take the necessary responsibilities for change (Carlson, Sperry, \& Lewis, 2005; Dattilio, 2018; Gladding, 2017; Nichols, 2013).

Spiritual beliefs and applications nourish families and societies, bind them together, facilitate healing in times of crisis, and encourage solidarity in the face of 
long-term problems (Walsh, 2009). As a result, we believe it is important to include spiritually oriented applications while addressing family members' problems during CBFT processes. Based on this importance, this study seeks to perform an in-depth investigation of spiritually oriented CBFT.

\section{Spiritually-Oriented Cognitive-Behavioral Family Therapy}

Just as there are several factors like race, family processes, social environment, and cultural context that influence individuals in their everyday life, spiritual and religious orientation not only affects how individuals perceive and give meaning to themselves, the events around them, and the greater world, but also shapes individuals' thoughts, emotions, and behaviors. Accordingly, we believe that since spiritual and religious orientation holds a significant position in the lives of many clients and is therefore an integral component in the therapeutic process (Paloutzian \& Park, 2005; Pargament, 2007).

Human experiences are expressed in five fundamental dimensions: psychological, social, moral, somatic, and spiritual. In clinical applications, the spiritual dimension constitutes the foundation element to all other dimensions of human experiences and is in a holistic relationship with them (Sperry, 2012).

We believe that following a CB approach during therapy with clients whose religious/spiritual dimension is preeminent - and who therefore bring with them problems of a spiritual or religious nature - would be beneficial. First of all, CBT is considered a powerful approach because it not only focuses on the core beliefs and assumptions of clients but also assesses assumptions from various angles, namely through the triangle of feelings, thoughts, and behaviors. Secondly, since CBT emphasizes education, take-home tasks incorporating reading sacred texts or integrated religious activities (e.g., relaxation, supplication, imagery) will not be foreign to religious clients. Finally, in addition to its emphasis on modifying and transforming cognitions and beliefs, CBT is very often viewed favorably by religious clients because of its emphasis on hard work's central role in realizing growth and change. Most doctrines, stories, and major traditional religions emphasize making changes in one's mind, heart, and behaviors while identifying various approaches like supplication, fasting, memorizing sacred texts, and confession rituals to be drivers of personal transformation (Nielsen, Johnson, \& Ellis, 2001; Tan \& Johnson, 2007).

Spiritually-oriented CBT does have both strengths and weaknesses. Its strengths include its provision of horizontal and vertical social support, building divine coping resources, and increasing spiritual motivation. Horizontal support includes support from people in one's environment, spiritual groups, and community projects of a spiritual nature whereas vertical support refers to support from a higher power, God, and a transcendent 
being. Divine coping resources are those that benefit from one's relationship with God or spiritual orientation. With regard to increasing spiritual motivation, as clients gain an understanding of themselves and are encouraged to modify aspects of their identity, they simultaneously gain a new source of motivation. Moreover, clients' motivation increases as they exchange negative, self-destructive labels with positive ones. The weaknesses of this approach, however, include belief imposition and the possibility of offending/ straining the client. With spirituality's integration into CBT, the client may fear that his/ her religious values and autonomy will not be respected and there is the risk that the therapist's own orientation might be imposed on the client. Moreover, incorporating spirituality into CBT may cause clients that have had negative experiences with religion discomfort. Consequently, these strengths and weaknesses must be taken into consideration while implementing Spiritually-oriented CBT in order that therapy may be as effective as possible (Hodge \& Lietz, 2014).

\section{Assessing Religion and Spirituality in CBT}

Four components (i.e., orientation, functional assessment, collaboration, monitoring) are considered while assessing clients' religious and spiritual elements in CBT (Rosmarin, 2018).

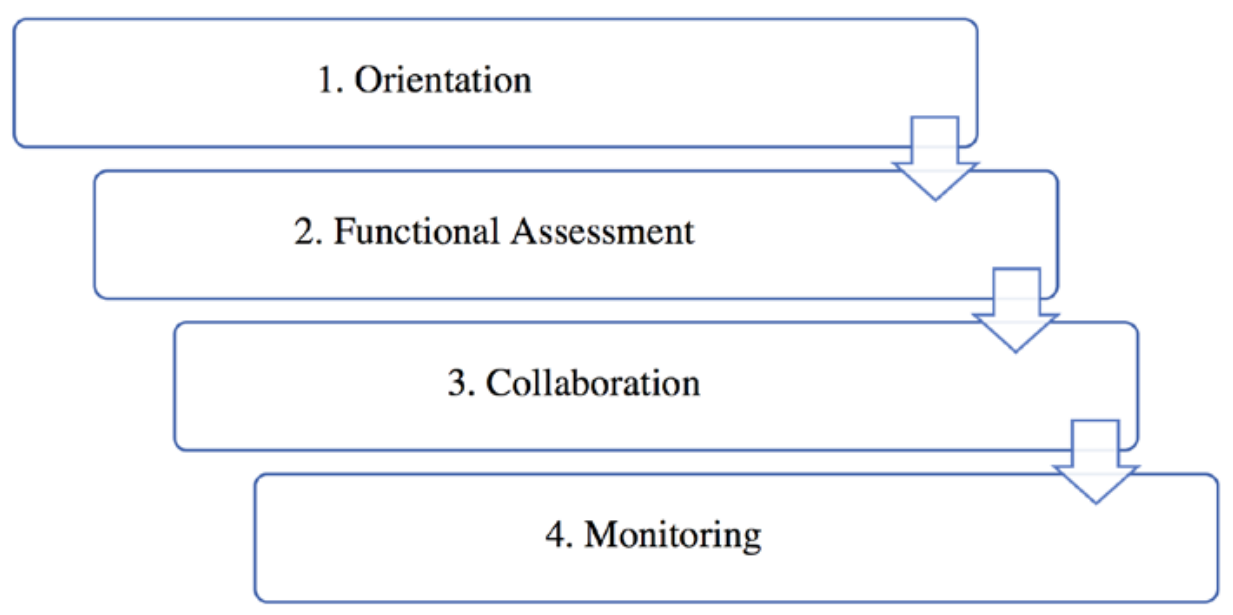

Figure 1.

Assessment Process of Religion and Spirituality in CBT According to Rosmarin (2018)

Rosmarin (2018) assesses religion and spirituality in four steps:

1. Orientation. During the first stage, informed consent is sought as to whether the client wants religion and spirituality to be included in the therapeutic process, the client is given an introduction to relevant topics, and information about the client is collected. The following questions may be helpful in realizing these aims: 
- In your opinion, is it a problem if I ask you about religion and spirituality?

- How important are religion and spirituality in your life?

- Have you always been this way?

- Do you have any spiritual or religious beliefs? (If yes, what are they?)

- Do you participate in any spiritual or religious activities? (If yes, how frequently?)

- Is it a problem for you if I were to bring up religion and spirituality for further discussion at this point?

2. Functional Assessment. The objective during the second stage is to direct the client to focus on treatment, to discover relationships between religion/spirituality and current problems and to formulate the relevance between religion/spirituality and the problems presented. Here, psycho educational processes can be benefited from in order to explain the relationship between religion/spirituality and the client's problems. While integrating CBT with religion/spirituality, it is important that client's spiritual paradigm resemble the cognitive model presented so that $\mathrm{s} /$ he may understand that cognitions are integral in arranging feelings and come to the realization that core beliefs influence people's reactions to certain stimuli. The following points should be focused on so that the objectives of functional assessment may be realized:

- What is the relationship between religion/spirituality and your symptoms?

- Do your religious/spiritual beliefs or activities help you cope with your problems?

- Does religion/spirituality exacerbate your symptoms?

- Do your religiosity and spirituality fluctuate based on religious/spiritual activities?

3. Collaboration. The primary objective of this stage is for offer the client and therapist a greater opportunity to discover the relevance between religion/spirituality and the problem presented, to strengthen the collaborative structure of the assessment and therapeutic process, and to strengthen the experimental structure of therapy. During this stage, the main goal is to integrate CBT techniques and applications with the religious/spiritual process by discovering the relationship between religion/ spirituality and the client's problem so that the client may cope with problems. The following points may be focused on during this step:

- Would you like to investigate further into how religion/spirituality may be related with your treatment? 
- Last week, did you feel anything different about how religion/spirituality is related to your symptoms?

- Would you like to learn whether anyone's symptoms have been affected by the use of any of these applications?

4. Monitoring. The final stage seeks to identify the positive and negative effects that including religion and spirituality had on treatment goals and to give clients the opportunity to provide feedback. The following topics are discussed:

- Did you notice any effect on your symptoms?

- Did our discussion about the religious and spiritual meaning of your treatment affect your participation or motivation in any way?

As a result, even if CBT therapists are not familiar with religion and spirituality, they should gather information about their clients and should investigate clients' problems by taking this four-stage assessment process as their basis. More importantly, integrating religion and spirituality into the CBT process allows clients' problems to be assessed from multiple angles (Rosmarin, 2018).

\section{Spiritual-Religious Framing of CBT}

Religion and spirituality strengthen individuals' capacity to overcome their natural cognitive, emotional, and behavioral reactions, thereby increasing individuals' self control (McCullough \& Carter, 2013; McCullough \& Willoughby, 2009). Religion and spirituality are able to present CBT techniques in a spiritual framework, which may strengthen clients' motivation to participate in therapy sessions and simultaneously increase their compatibility with the techniques used. Furthermore, by integrating religion and spirituality with CBT, clients may understand CBT concepts more easily and therefore achieve better results from CBT therapy (Hodge, 2006; Rosmarin, 2018).

While framing CBT with religion and spirituality, it is important to:

- Structure therapy in line with religious/spiritual directives and sacred scriptures,

- Incorporate religion and spirituality in such a way that emphasizes that the emotional significance of therapy is just as important as its spiritual significance in order frame obstacles to and difficulties faced during therapy,

- Use religious/spiritual texts to lead discussion on the interaction between feelings and thoughts at the core of CT ("Change your thoughts", "Our life is shaped around our mind, we are what we think"), 
- Stress the importance of spirituality in changing behaviors since one's feelings toward spiritual/religious belief systems are directly shaped by behavior,

- Formulate exposure therapy through beliefs that have spiritual and religious importance,

- Frame behavioral activation in a spiritual paradigm to encourage clients to participate in social, enjoyable, and nurturing activities so that they may enhance their emotional capacities,

- Ground behavioral activation in a spiritual framework that is in line with the specific way that the client perceives God's role in everyday life, as different religious beliefs and cultures perceive His role differently,

- Structure CBT with religious and spiritual elements so as to prevent negative events and situations from emerging as a result of clients' intolerance toward uncertainly (spiritual CBT approaches that build clients' tolerance to uncertainty help them accept the limits of their own ability to comprehend the divine, thereby increasing humbleness),

- Base therapy on the notion that learning how to overcome one's fear of negative evaluations will facilitate their attainment of spiritual freedom, and

- Structure spiritually-centered CBT in such a way that deals with perfectionism and since self-oriented perfectionism is a risk factor in a number of psychiatric disorders (Rosmarin, 2018).

Here, we have presented examples from individual psychological counseling to show how religion and spirituality may be framed in CBT, and particularly in how religion and spirituality may be assessed in it. Since similar stages also exist in Spiritually-Oriented Cognitive-Behavioral Family Therapy, we will discuss them in light of family members and family systems.

\section{Fundamental Techniques and Applications in Spiritually-Oriented CBFT}

Spiritually-oriented CBFT realizes a variety of applications that incorporate religious and spiritual elements and then synthesizes them with classic CBT techniques to form a holistic approach. 


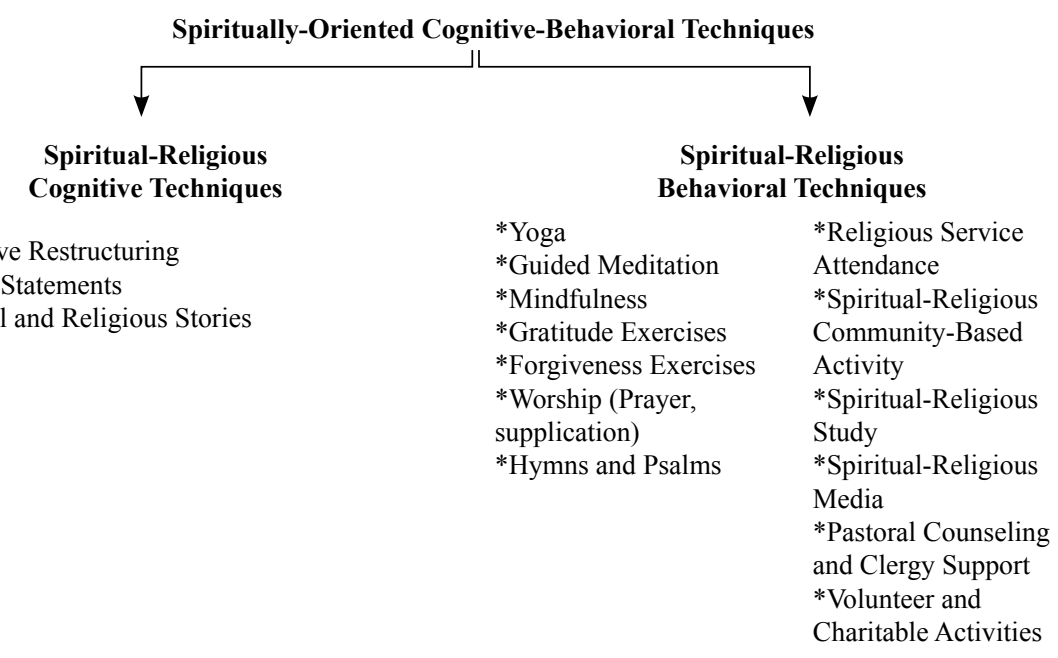

* Cognitive Restructuring

*Coping Statements

* Spiritual and Religious Stories

\section{Figure 2.}

Spiritually Oriented Cognitive-Behavioral Techniques According to Rosmarin (2018)

Cognitive Restructuring. In order to elicit emotional change in clients, they must first realize cognitive distortions, otherwise known as irrational or inaccurate thoughts and beliefs, and then exchange them with positive, rational beliefs. Clients also have cognitive distortions related to their religious/spiritual orientations that influence their daily lives. Clients can therefore make use of religious texts in line with their own beliefs to exchange their cognitive distortions with rational beliefs during the spiritual-cognitive restructuring process (Barrera, Zeno, Bush, Barber, \& Stanley, 2012; Carlson \& Gonzalez-Prendes, 2016; Hamdan, 2008; Rosmarin, 2018).

A Muslim client may express such beliefs and negative thoughts as "Life is very difficult", "I'm alone", and/or "I can't cope" that can be reframed through various Qur'anic verses during the spiritual-cognitive restructuring process implemented during counseling. Clients' negative thoughts can be transformed into positive ones by discussing in light of different Qur'anic verses (Lodi, 2018). For example, instead of life's being very difficult, the client can be presented with "Allah intends for you ease and does not intend for you hardship" (Qur'an 2:185) ; $^{3}$ instead of loneliness, "And We have already created man and know what his soul whispers to him, and We are closer to him than [his] jugular vein" (Qur'an 50:16); and instead of not being able to cope, "Allah does not charge a soul except [with that within] its capacity" (Qur'an 2:286). Likewise, Christian clients can be presented texts from their own sacred texts, like the Old Testament, during therapy. For example, in Psalm 88, the psalmist states that he has been shaken by God as a result of negative events, but since they show that God is behind all of these events, they serve a positive end. Building

3 All translations of the Qur'an are from Sahih International. 
off of this, clients can be encouraged to restructure their cognitions (Rosmarin, 2018). An example of spiritual-cognitive restructuring in spiritually-oriented CBFT would be to use Islamic teachings from the Qur'an and sunnah of the Prophet Muhammad to exchange irrational and illogical assessments underlying a Muslim client's thoughts and beliefs with rational ones while also keeping in mind the cognitive differences between men and women, (Khakpour et al., 2018).

Coping Statements. are statements that help clients overcome the stressful thoughts they experience during difficult situations and that act as aids to accepting accurate, positive thoughts. In spiritual CBT, clients can indoctrinate themselves and combat a variety of problems by using coping statements like "Even when I feel alone, God is always nearby", "This will pass", and "No matter how bad things get, I'm never alone" (Rosmarin, 2018). Clients who incorporate statements like "God is good", "God is peace", and "I am good and joyful" together with daily 20-minute progressive muscle relaxation exercises are observed to have more positive psychological and spiritual states of well-being (Wachholtz \& Pargament, 2005). In a study where spirituality was integrated with CBFT, family members were asked to reflect over religious statements, to realize God's compassion in their own lives, and to contemplate on the belief that hopelessness is the greatest sin and therefore discover the impact of spirituality and religious commands in their daily lives (Khodayarifard \& Fatemi, 2013).

Spiritual and Religious Stories. In spiritually-oriented CBT, spiritual and religious stories in line with clients' beliefs may be used to analyze cognitive structures, regulate emotions, and reframe them (Good, 2010; Rosmarin, 2018). Incorporating stories has recently become popular in CBT applications (Blenkiron, 2005; Stott \& Salkovskis, 2010). The use of religious and spiritual stories offers clients the opportunity to regulate their emotions, reduce stress, improve their mood, and modify their behaviors (Otto, 2000). Even if they be of different religions or belief systems, many stories contain anecdotes that trigger spiritual emotions like honesty, love, forgiveness, gratitude, courage that offer clients an alternative to destructive thoughts (Rosmarin, 2018). Including stories about prophets mentioned in the Qur'an during family therapy with Muslim clients offers family members the opportunity to assess their problems in light of a different narrative, thereby facilitating in-family conflict resolution (Malik, 2018).

Yoga. Incorporating basic meditation, breath control, and flexibility, yoga is a technique that seeks to focus on the mind, calm the practitioner, bring about physical comfort, develop internal awareness, and, as a result, facilitate happiness, well-being, awareness, and spiritual growth in individuals (Valente \& Marotta, 2011). Yoga is commonly used in CBT applications to treat problems like depression and anxiety and there are studies examining yoga's effects and benefits in this very vein (Shapiro et al., 2007; Vinod, Vinod, \& Khire, 1991). Conducting a study on family therapy with families of children 
diagnosed with ADHD, Harrison, Monacha, and Rubi (2004) found that children's ADHD symptoms declined after having participated in yoga meditation exercises twice a week over a six-week period, that their self-confidence increased, that the relationship quality with their parents improved, that they felt happier and less stressed, and that they were better able to manage their behaviors. In their study conducted with children and parents diagnosed with cancer, Thygeson et al. (2004) found that including yoga in family therapy sessions helped significantly reduce parents' anxiety levels. In a study with high-achieving children and parents, Quast (2014) found that including integrated yoga and CBT (Yogerapy) in addition to such techniques as cognitive restructuring, coercive thoughts, progressive muscle relaxation, and coping skills during family-based therapy treating problems and anxiety constituted an effective intervention method because it incorporates families' strengths, cooperation, and parent support.

Guided Meditation. is a technique that incorporates exercises done either individually or while following an audio or video recording under the guidance of a teacher or leader. The main objective of this technique is to have clients focus on their own breathing, to engage in body scan meditation, and to attempt to eliminate anxiety. In spirituallyoriented CBT, guided meditation can be used as a behavioral approach to help clients manage problems and stress (D'Souza \& Rodrigo, 2004; Kristeller, 2011; Rosmarin, 2018). Integrating meditation in family and couples therapy can enliven communication and interaction between individuals. Guided meditation seeks to achieve the following objectives during family therapy: (i) to reduce emotional reactivity between family members, (ii) to facilitate intimate with deep listening with others, (iii) to aid in family members' recovery and reconnection after loss, (iv) to stimulate compromise among family members, and (v) to implement techniques that encourage family members to adopt spirituality in their lives (Gale, 2009).

Mindfulness. is a mental exercise characterized by conscious awareness and focused attention where an individual attempts to concentrate on his/her feelings, to perceive foreign thoughts in a calm manner, and to make decisions without judgment. During spiritually-oriented CBT, mindfulness allows the individual to reduce the effects of anxiety and stress, to identify and manage negative thoughts, to learn how to remain calm, to practice breathing exercises that reduce negative thoughts, and organize cognitions and feelings (Benson \& Klipper, 2000; Carlson \& Gonzalez-Prendes, 2016; Ladner, 2011). Integrating non-judgmental mindfulness into marriage and family therapy is important in that it promotes communication, emotional regulation, empathy, and relational well-being in couples and family members (Gambrel \& Keeling, 2010).

Gratitude Exercises. Implemented in spiritual CBT with clients wishing to include religious and/or spiritual elements in the therapeutic process, gratitude exercises are activities where an individual expresses thanks and gratitude to God or a higher power 
in response to positive life events and positive aspects of self. By having clients imagine how they have coped with past stress and difficult situations, they realize the importance of religious/spiritual power in coping, which can then be channeled into gratitude toward God and used to strengthen future resilience (Rosmarin, 2018; Rosmarin, Auerbach, Bigda-Peyton, Björgvinsson, \& Levendusky, 2011). In religious $\mathrm{CBT}$, gratitude exercises, like composing a gratitude list, counting thanks, writing a gratitude letter, reading religious stories and texts that increase gratitude, and using role models in holy books to express one's gratitude, have been found to play a significant role in reducing depression in individuals (Pearce et al., 2016). Experiencing positive emotions like gratitude among family members is related to family satisfactions (Williams, 2012).

Forgiveness Exercises. Forgiveness is defined as the intentional decision to release negative feelings, thoughts, and behaviors like retaliation against a person or group that has caused harmed to one and the simultaneous ability to display a positive stance toward said person or group (McCullough, Pargament, \& Thoresen, 2000). All religions emphasize rituals, role models, and worldviews that facilitate acceptance and encourage forgiveness (McCullough \& Worthington, 1999). Forgiveness models and techniques are used to transform negative feelings and thoughts into positive ones in spiritually-oriented CBT (Rosmarin, 2018). Forgiveness has a wide range of positive effects on individual characteristics, parent-child relationships, and the general family environment (Maio, Thomas, Fincham, \& Carnelley, 2008). Looking at the role of forgiveness in marriage and family processes reveals there to be significant relationships between forgiving marital betrayal, marriage satisfaction, parental accord, and how children perceive their parents' marriage (Gordon, Hughes, Tomcik, Dixon, \& Litzinger, 2009). By practicing forgiveness in family-of-origin sessions, we observe that family relationships are strengthened when family members make cognitive choices that encourage being at peace with God and that forgiveness strategies are effective in breaking dysfunctional patterns from the past that have been carried into one's new family (DiBlasio, 1998).

\section{Spiritual-Based Applications in Cognitive-Behavioral Family Therapy}

Khodayarifard and Fatemi (2013) conducted a study on combining spirituality and CBFT during the treatment of common anxiety disorders. In their study, in addition to implementing several $\mathrm{CB}$ techniques like self-observations, positive thinking, cognitive restructuring, creative desensitization, counseling sessions were organized both individually and together with family members. Therapists worked on certain skills like discussing anxiety and family conflicts with family members and problem solving. Integrating spirituality with CBFT, love shared with all humans, monotheism, and belief in Judgment Day and the afterlife were emphasized. A number of religious and spiritual exercises focusing on the relationship between 
meaning and God, between values and spirituality, and between responsibility and the soul were implemented during discussions with family members. Family members were asked to reflect over religious statements, to realize God's compassion in their own lives, and to contemplate on the belief that hopelessness is the greatest sin and were then helped to discover the impact of spirituality and religious commands in their own phenomenological lives and daily experiences. As a result of their study, Khodayarifard and Fatemi (2013) found that integrating spirituality with CBFT was effective in reducing family members' anxiety levels, in changing thought patterns within the family, and in increasing social competency.

An important approach in studies conducted with families, the BiopsychosocialSpiritual (BPSS) Model focuses on individuals' personal characteristics (e.g., cognitions, beliefs, feelings, behaviors, and spirituality) and on all system levels incorporating families, other intimate relationships, and cultural and social characteristics. In marriage and family therapy, the BPSS model underlines the critical role of health and illness experiences, cognitive processes, and spiritual/religious belief systems while coping with problems (Prest \& Robinson, 2006; Walsh, 2009; Wright, Watson, \& Bell, 1996).

Prest and Robinson (2006) touch on the importance of the BPSS model in assessing and treating depression and anxiety in families, highlighting the six CB and spiritualreligious dimensions composing it: (i) biological factors, (ii) behavioral coping and stress management factors, (iii) factors pertaining to $\mathrm{CB}$ coping and meaning formation, (iv) factors pertaining to family and couple dynamics, (v) factors pertaining to spiritual-religious resources and belief systems, and (vi) socio-cultural contextual factors. Biological factors include a physical medical evaluation, improved nutrition, and a reduction in stimuli. Behavioral coping and stress management focus on techniques like mediation, yoga, breathing exercises, progressive muscle relaxation, and desensitization. CB coping and meaning formation concentrate on identifying and addressing family members' perspectives related to the circumstances that accompany anxiety and depression, defusing irrational beliefs, and realizing emotional reaction patterns. Family and couple dynamics focus on changing relational patterns, family roles, and feedback, exploring feelings while actualizing change, and recommending behaviors that encourage problem and conflict resolution. Spiritual-religious resources and belief systems seek to discover systems of meaning by focusing on the meanings of life events, loss, and illnesses, collaborating with clergymen, to make supplications, reading, and to encourage clients to accept support from others as a form of coping. Socio-cultural contextual factors focus on exploring the effect of racial, ethnic, and cultural context and on realizing cooperation with social systems. Employing the BPSS model, therapists are able to address a variety of diverse dimensions with families and incorporate spiritual, cognitive, and behavioral structures in the process. 
Investigating the dynamics of infertile couples participating in religious belief-based activities, Smith and Smith (2004) examined the effects of religious communities and spiritual activities on families' self-esteem and found that CB counseling was an effective intervention technique to be used during crises experienced by infertile couples. Employing CBT, the counselors attempted to help infertile couples locate negative thought patterns, which may have solidified over many years, and then to aid them in exchanging these patterns with positive ones. Couples have at their disposal a various techniques to help them develop optimistic attitudes toward themselves and their marriage and also to facilitate their abandonment of whatever pessimist views they may have. A variety of techniques are employed in belief-based CBT; these include comforting techniques, focusing on cognitive disorders, cognitive structuring, planned activities, modifying cognitive errors, cultivating empathy in the family, discussing myths about infertility, and exposing sensory focusing. Couples experiencing an emotional crisis frequently find themselves embroiled in spirituality and may have several spiritual-religious automatic thoughts. Consequently, CBT therapists play an instrumental role in helping them realize their spiritual-religious distortions. During the process, individuals are able to express their anxieties in a safe environment, and this awareness can increase the possibility of dialogue and positive participation. Moreover, as a result of the psychosocial effects of participating in activities grounded in one's religious beliefs, clients tend to have an easier time distancing themselves from negative thoughts.

Conducting a study with individuals whose spouse was addicted to one or more narcotic substances, Khakpour et al. (2018) examined the effects of family therapy on marriage satisfaction. To this end, they designed a program following a CBT model composed of ten spiritual family therapy sessions. The content of these sessions were as follows:

i. Establishing positive, safe, and healthy relationships with one's spouse, recognizing Islam's view on the importance and objective of marriage and on the rights and duties of spouses, performing ritual prayers and reading memorized portions of the Qur'an with the awareness that at least one sign refers to one's spouse, and writing down comments about the actions of one's spouse separately.

ii. Brief rundown of the previous session in order to identify stress, personality, family conflict, family expectations, mutual expectations, and the thoughts and feelings of one's spouse. Going over take-home tasks, individual assessments, and the clinical sessions of both partners. Take-home task: Both partners are asked to write down conflict, mutual expectations, thoughts, and feelings on a separate chart. 
iii. Brief discussion of previous sessions and take-home tasks. Reviewing the cognitive differences between men and women. Discussion on self-education, couples education. Recognizing cognitive errors, emotions and negative feelings. Employing the Qur'an and sunnah to exchange irrational and illogical assumptions underlying thoughts and believes with rational ones. Take-home task: Spouses are asked to monitor and record cognitive errors individually.

iv. Analysis of previous sessions and discussion of take-home tasks. Evaluation of negative thoughts. Encouraging clients to challenge their negative thoughts by framing problems and relevant situations in a Qur'anic context and by strengthening one's forbearance and trust in the Lord (i.e., Allah). Take-home task: Spouses are asked to monitor their negative thoughts and partner and to write them down individually.

v. Brief discussion of the previous session and take-home tasks. Fifteen minutes of muscle relaxation and deep breath exercises. Aiding partners to discover their own ideas. Discussing rational thoughts, feelings, and couples to precipitate the exchange of irrational and negative thoughts with rational and positive ones. Take-home task: Spouses are asked to challenge irrational thoughts and write down cognitive errors.

vi. Brief discussion of previous sessions and take-home tasks, education, and sources of knowledge (e.g., self observations, social feedback, social comparisons). Addressing their affects on spousal relationships. Take-out task: Spouses are asked to relate belief and behavior indicators with sources of knowledge.

vii. Brief discussion of previous sessions and take-home tasks. Learning how to engage in verbal and non-verbal communication with respect, politeness, forbearance, and forgiveness in light of divine commands. Learning obstacles to communication (e.g., commands, threats, recommendations, persuasion, judging and criticizing, objections, accusing others, belittlement, and retaliation). Take-home task: Spouses are asked to list effective and noneffective verbal and non-verbal behaviors in a chart.

viii. Brief discussion of previous sessions and take-home tasks. Effective dialogue skills (expression, expression). Aggressive dialogue control, active listening skills (e.g., attention, signaling, invitation, summarizing, and asking questions). Takehome task: Spouses are asked to depict the skills they use on separate charts.

ix. Brief review of previous sessions and take-home tasks. Understanding education, respect, empathy, and one's partner. Gratitude, adornment and cleanliness, gifts, and cooperation in housework. Understanding gender (e.g., 
cognitive differences, desires, and wants). Take-home task: Spouses are asked to put these skills into practice and to write down their comments on their behavior toward their partner separately.

x. Summary, conclusions reached, and program evaluation with both partners (e.g., opinions of the program, strong and weak points).

Khakpour et al. (2018) found that after 10 sessions of CBT-based spiritual family therapy with couples, both partners' marriage satisfaction, positive thoughts, problem-solving skills, personal behaviors, emotions, and religious orientations significantly improved.

Conducting their study in Iran, Khodayarifard and McClenon (2012) discuss Islamically-based CBFT and its application in obsessive compulsive disorder. Muslim therapists believe that special methods should be used during therapy since Muslim families have distinct characteristics. The researchers state that integrating Islamic features to CBT, which is already one of the most effective therapy approaches to obsessive compulsive disorder, will only further enhance its effectiveness with Muslim clients. Islamic CBT is grounded in the Qur'an, hadith literature, sunnah (i.e., sayings and practices of the Prophet Muhammad), tawhid (Islamic monotheism), the meaning of life, spiritual salvation, and mental well-being. Islamically inappropriate schemata can be modified with culturally and theologically appropriate variations during the therapeutic process. Negative beliefs can be exchanged with rational ones through supplication, rituals, moral behaviors, and religiosity. During therapy, automatic beliefs can be exchanged with Qur'an-centric, Islamic beliefs. Exercises aiding clients to focus on the afterlife, to reevaluate the meanings of problems, to remember Allah, to trust in Allah, and to focus on Allah may also be incorporated into the larger therapeutic process.

\section{Conclusion}

Integrating spiritually-oriented psychotherapy and spiritually-centered interventions into psychological counseling and psychotherapy has been actively pursued worldwide and has, as a result, compiled a large body of relevant literature (Aten, McMinn, \& Worthington, 2011; Pargament, 2007; Sperry \& Shafranske, 2007). One of the approaches very frequently used in spiritually-oriented psychotherapy that has been attested to by many researchers is Spiritually-Oriented Cognitive-Behavioral Therapy (Rosmarin, 2018; Tan \& Johnson, 2007). In spiritually-oriented CBT, we see that (i) classic $\mathrm{CB}$ techniques and applications are integrated with clients' own spiritual/ religious backgrounds, (ii) clients refer to sacred texts from own religious/spiritual tradition while dealing with cognitive distortions, and (iii) a variety of exercises promoting forgiveness, gratitude, meditation, mindfulness, and spiritual coping are 
incorporated to facilitate behavioral activation and the consolidation of cognitive structures (Carlson \& Gonzalez-Prendes, 2016; Good, 2010; Hodge, 2006; Rosmarin, 2018; Rosmarin et al., 2011).

Spiritually-oriented CBT has been found to be an effective approach when addressing problems like anxiety (Paukert et al., 2009; Rosmarin, Bocanegra, Hoffnung, \& Appel, 2019), depression (Good, 2010; Kausar \& Bhutto, 2018; Koenig, Pearce, Nelson, \& Erkanli, 2016; Pearce et al., 2016), and addiction (Hodge \& Lierz, 2014). Moreover, CBT applications involving diverse religious groups like Muslims (Hamdan, 2008; Hodge \& Nadir, 2008; Khodabakhshi, Mohammadi, Taghavi, \& Rahimi, 2015; Lodi, 2018; Naeem et al., 2015), Christians (Buju, 2019; Hawkins, Tan \& Turk, 1999; Pearce \& Koenig, 2013), and Jews (Rosmarin, 2010; Rosmarin et al., 2019) have been conducted. Although the international literature is rich in theoretical and practical studies, spiritually-oriented CBT studies are still in their infant stages in Turkey.

Since Spiritually-Oriented Cognitive-Behavioral Family Therapy has only recently been included among the categories of family therapy types in Cognitive-Behavioral Family Therapy, there are only a limited number of studies in the literature on it. Even if few in number, Khodayarifard and McClenon (2011), Khakpour et al. (2018), Smith and Smith (2004), Prest and Robinson (2006), and Khodayarifard and Fatemi (2013) have conducted diverse studies on spiritually-oriented CBFT.

Since the first environment humans find themselves upon coming into this world is the family environment, parenting styles and since traditional values passed down from previous generations, family communication and interaction play a vital role in individuals' development and psychological health, the importance of family therapy is quite apparent. As a result, spiritually-oriented applications are needed for clients for whom spirituality and religion are central to their lives and who want to address them during psychotherapy in family therapy conducted simultaneously with multiple family members. Here, we believe that our study will offer practitioners and researchers different perspectives concerning spiritually-oriented CBFT. Given, however, that spiritual-oriented family therapy is in its beginning stages in Turkey, experimental studies on Turkish culture, beliefs, and spiritual values are of great need. Consequently, there is a pressing need to develop diverse spiritually-centered therapy techniques, structured programs, and applications that take into consideration the religious and spiritual particularities of Turkey. Furthermore, it is important that psychological counselors working in the field participate in training programs on religious/spiritual counseling skills in addition to their general therapy education.

Acknowledgement This article does not involve any human participant data, and thus no ethical approval was required. 


\section{References}

Arnkoff, D. B., \& Glass, C. R. (1992). Cognitive therapy and psychotherapy integration. In D. K. Freedheim (Ed.), History of psychotherapy; A century of change (pp. 657-694). Washington: American Psychological Association.

Aten, J. D., McMinn, M. R. \& Worthington, E. L. (2011). Spiritually oriented interventions for counseling and psychotherapy. Washington: American Psychological Association.

Barrera, T. L., Zeno, D., Bush, A. L., Barber, C. R., \& Stanley, M. A. (2012). Integrating religion and spirituality into treatment for late-life anxiety: Three case studies. Cognitive and Behavioral Practice, 19(2), 346-358.

Beck, J. S. (1995). Cognitive therapy: Basics and beyond. New York: The Guilford Press.

Beck, A. T. (1979). Cognitive therapy and emotional disorders. New York: Penguin Group.

Beck, A. T. (2005). The current state of cognitive therapy A 40-year retrospective. Arch Gen Psychiatry, 62, 953-959.

Beck, A. T., \& Weishaar, M. E. (2008). Cognitive therapy. In R. J. Corsini, \& D. Wedding (Eds.), Current psychotherapies (pp. 263-294). Belmont: Brooks.

Bennett, S. T., Flett, R. A., \& Babbage, D. R. (2014). Culturally adapted cognitive behaviour therapy for Maori with major depression. The Cognitive Behaviour Therapist, 7, 1-16.

Benson, H., \& Klipper, M. (2000). The relaxtion response. New York: Avon.

Blenkiron, P. (2005). Stories and analogies in cognitive behaviour therapy: A clinical review. Behavioural and Cognitive Psychotherapy, 33(1), 45-59.

Buju, S. (2019). Clinical approach of spiritual illnesses: Eastern Christian spirituality and cognitive behavioral therapy. Pastoral Psychology, 68, 361-378.

Carlson, K. M., \& González-Prendes, A. A. (2016). Cognitive behavioral therapy with religious and spiritual clients: A critical perspective. Journal of Spirituality in Mental Health, 18(4), 253-282.

Carlson, J., Sperry, L., \& Lewis, J. A. (2005). Family therapy techniques. New York: Routledge Taylor \& Francis Group.

Corey, G. (2015). Psikolojik danışma, psikoterapi kuram ve uygulamaları. (T. Ergene, Çev.). Ankara: Mentis Yayıncılık.

Dattilio, F. M. (1998). Case studies in couple and family therapy: Systemic and cognitive perspectives. New York: Guilford Press.

Dattilio, F. M. (2005). The restructing of family schemas: A cognitive-behavioral perspective. Journal of Marital and Family Therapy, 31(1), 15-30.

Dattilio, F. M. (2018). Bilişsel davranışçı çift ve aile terapisi klinisyenler için bir rehber (T. Özakkaş, Çev.). İstanbul: Psikoterapi Enstitüsü Eğitim Yayınları.

DeRubeis, J. R., \& Beck, A.T. (1988). Cognitive therapy. In K. S. Dobson (Ed.), Handbook of cognitive behavioral therapies (pp. 273-306). New York: Guilford Press.

DiBlasio, F. A. (1998). The use of a decision-based forgiveness intervention within intergenerational family therapy. Journal of Family Therapy, 20(1), 77-96.

Digiuseppe, R. A., Doyle, K. A., Dryden, W., \& Backx, W. (2013). A practitioner's guide to rational emotive behavior therapy. New York: Oxford University Press.

Dryden W., \& Neenan, M. (2006). Rational emotive behaviour therapy 100 key points \& techniques. New York: Routledge Taylor \& Francis Group. 
D’Souza, R. F., \& Rodrigo, A. (2004). Spiritually augmented cognitive behavioural therapy. Australasian Psychiatry, 12(2), 148-152.

Ellis, A. (1978). Family therapy: A phenomenological and active-directive approach. Journal of Marriage and Family Counseling, 4, 43-50.

Ellis, A. (2001). Overcoming destructive beliefs, feelings, and behaviors new directions for rational emotive behavior therapy. Canada: Prometheus Books.

Ellis, S. (2007). A rational emotive behavior therapy integrated approach overcoming resistance. New York: Springer Publishing Company.

Ellis A., \& Dryden, W. (1997). The practice of rational emotive behavior therapy. New York: Springer Publishing Company.

Ellis, A., Sichel, J. L., Yeager, R. J., DiMattia, D. J., \& DiGiuseppe, R. (1989). Rational-emotive couples therapy. New York: Pergamon Press.

Epstein, N. B., \& Baucom, D. H. (2002). Enhanced cognitive-behavior therapy for couples: A contextual approach. Washington, DC: American Psychological Association.

Epstein, N., \& Schlesinger, S. E. (1996). Cognitive-behavioral treatment of family problems. In M. Reinecke, F. M. Dattilio, \& A. Freeman (Eds.), Casebook of cognitive-behavior therapy with children and adolescents. New York: Guilford Press.

Gale, J. (2009). Meditation and relational connectedness: Practices for couples and families. In F. Walsh (Ed.), Spiritual resources in family therapy (pp. 247-266). New York: The Guilford Press.

Gambrel, L. E., \& Keeling, M. L. (2010). Relational aspects of mindfulness: Implications for the practice of marriage and family therapy. Contemporary Family Therapy, 32(4), 412-426.

Gladding, S. T. (2017). Aile terapisi tarihi, kuram ve uygulamaları. (İ. Keklik ve İ. Yıldırım, Çev.). Ankara: Türk Psikolojik Danışma ve Rehberlik Derneği Yayınları.

Goldenberg, H., \& Goldenberg, I. (2008). Family therapy: An overview. USA: Thamson.

Good, J. J. (2010). Integration of spirituality and cognitive-behavioral therapy for the treatment of depression (Unpublished Doctoral dissertation). Philadelphia College of Osteopathic Medicine, Philadelphia.

Gordon, K. C., Hughes, F. M., Tomcik, N. D., Dixon, L. J., \& Litzinger, S. C. (2009). Widening spheres of impact: The role of forgiveness in marital and family functioning. Journal of Family Psychology, 23(1), 1.

Hamdan, A. (2008). Cognitive restructuring: An islamic perspective. Journal of Muslim Mental Health, 3(1), 99-116.

Harrison, L. J., Manocha, R., \& Rubia, K. (2004). Sahaja yoga meditation as a family treatment programme for children with attention deficit-hyperactivity disorder. Clinical Child Psychology and Psychiatry, 9(4), 479-497.

Hawkins, R. S., Tan, S. Y., \& Turk, A. A. (1999). Secular versus Christian inpatient cognitivebehavioral therapy programs: Impact on depression and spiritual well-being. Journal of Psychology and Theology, 27(4), 309-318.

Hays, P. A. (2016). Addressing cultural complexities in practice: Assessment, diagnosis, and therapy (3rd ed.). Washington, DC: American Psychological Association.

Hodge, D. R. (2006). Spiritually modified cognitive therapy: A review of the literature. Social Work, 51(2), 157-166. 
Hodge, D. R., \& Lietz, C. A. (2014). Using spiritually modified cognitive-behavioral therapy in substance dependence treatment: Therapists' and clients' perceptions of the presumed benefits and limitations. Health \& Social Work, 39(4), 200-210.

Hodge, D. R., \& Nadir, A. (2008). Moving toward culturally competent practice with Muslims: Modifying cognitive therapy with Islamic tenets. Social Work, 53(1), 31-41.

Hofmann, S. G. (2013). The wiley handbook of cognitive behavioral therapy. London: WileyBlackwell.

Kausar, E., \& Bhutto, Z. H. (2018). Treatment of depression in cardiac patients through integration of spirituality and cognitive behavior therapy. Bahria Journal of Professional Psychology, 17(2), 89-103.

Kazantzis, N., Dattilio, F. M., \& Dobson, K. S. (2017). The therapeutic relationship in cognitivebehavioral therapy a clinican's guide. New York: The Guilford Press.

Khakpour, M., Mehrafarid, M., Akbari Amarghan, H., Nejat, H., Fazayeli Yousefabad, M., \& Toroghi, R. (2018). Effect of spiritual family therapy on marital satisfaction in couples with husbands' drug-dependent. Journal of Research and Health, 8(4), 365-372.

Khodabakhshi, K., Mohammadi, N., Taghavi, M., \& Rahimi, C. (2015). Study of effectiveness integrated spiritual-cognitive-behavioral group therapy with Islamic mysticism approach of depression, guilt feeling \& loneliness. Jurnal UMP Social Sciences and Technology Management, $3(1), 515-524$.

Khodayarifard, M., \& Fatemi, S. M. (2013). Combination of spirituality and cognitive-behavioral family therapy on treatment of generalized anxiety disorders. Psychology, 4(04), 427-432.

Khodayarifard, M., \& McClenon, J. (2011). Family therapy in Iran: A case study of obsessivecompulsive disorder. Journal of Multicultural Counseling and Development, 39(2), 78-89.

Koenig, H. G., Pearce, M. J., Nelson, B., \& Erkanli, A. (2016). Effects on daily spiritual experiences of religious versus conventional cognitive behavioral therapy for depression. Journal of Religion and Health, 55(5), 1763-1777.

Köroğlu, E. (2017). Akılcı duygulanım davranışçı terapi. Ankara: HYB Yayıncılık.

Kristeller, J. (2011). Spirituality and Meditation. In J. D. Aten, M. R. McMinn, \& E. L. Worthington (Eds.) Spiritually oriented interventions for counseling and psychotherapy. (pp. 197-227). Washington: American Psychological Association.

Ladner, L. (2011). Mindfulness. In J. D. Aten, M. R. McMinn, \& E. L. Worthington (Eds.) Spiritually oriented interventions for counseling and psychotherapy. (pp. 229-250). Washington: American Psychological Association.

Leahy, R. L. (2018). Bilişsel terapi ve uygulamaları tedavi müdahaleleri için bir kılavuz. (T. Özakkaş, Çev. Ed.). İstanbul: Litera Yayıncılık.

Lodi, F. (2018). The HEART method: Healthy emotions anchored in RasoolAllah's teachings: Cognitive therapy using Prophet Mohammed as a psycho-spiritual exemplar. In C. Y. Al-Karam (Ed.), Islamically integrated psychotherapy uniting faith and professional practice (pp. 76-102). USA: Templeton Press.

Maio, G. R., Thomas, G., Fincham, F. D., \& Carnelley, K. B. (2008). Unraveling the role of forgiveness in family relationships. Journal of Personality and Social Psychology, 94(2), 307.

Malik, R. (2018). Family therapy and the use of Quranic stories. In C. Y. Al-Karam (Ed.), Islamically integrated psychotherapy uniting faith and professional practice (pp. 152-174). USA: Templeton Press. 
McCullough, M. E., \& Carter, E. C. (2013). Religion, self-control, and self- regulation: How and why are they related? In K. I. Pargament, J. J. Exline, \& J. W. Jones (Eds), APA handbook of psychology, religion, and spirituality: Vol. 1. Context, theory, and research (pp. 123-138). Washington, DC: American Psychological Association.

McCullough, M. E., Pargement, K. I., \& Thoresen, C. E. (2000). Forgiveness: Theory, practice and research. New York: Guilford Press.

McCullough, M. E., \& Willoughby, B. L. (2009). Religion, self-regulation, and self-control: Associations, explanations, and implications. Psychological Bulletin, 135(1), 69-93.

McCullough, M. E., \& Worthington, E. L., Jr. (1999). Religion and the forgiving personality. Journal of Personality, 67(6), 1141-1164.

Murdock, L. N. (2014). Psikolojik danışma ve psikoterapi kuramları. (F. Akkoyun, Çev.). Ankara: Nobel Yayıncilık.

Naeem, F., Phiri, P., Munshi, T., Rathod, S., Ayub, M., Gobbi, M., \& Kingdon, D. (2015). Using cognitive behaviour therapy with South Asian Muslims: Findings from the culturally sensitive CBT project. International Review of Psychiatry, 27(3), 233-246.

Nichols, M. P. (2013). Aile terapisi kavramlar ve yöntemler. (O. Gündüz, Çev.). İstanbul: Kaknüs Yayınları.

Nielsen, S. L., Johnson, W. B., \& Ellis, A. (2001). Counseling and psychotherapy with religious persons a rational emotive behavior therapy approach. Mahwah: Lawrence Erlbaum Associates.

Northey, W. F. (2002). Characteristics and clinical practices of marriage and family therapists: A national survey. Journal of Marital and Family Therapy, 28, 487-494.

Otto, M. W. (2000). Stories and metaphors in cognitive-behavior therapy. Cognitive and Behavioral Practice, 7(2), 166-172.

Paloutzian, R. F., \& Park, C. L. (2005). Handbook of the psychology of religion and spirituality. New York: The Guilford Press.

Pargament, K. I. (2007). Spiritually integrated psychotherapy understanding and addressing the sacred. New York: The Guilford Press.

Paukert, A. L., Phillips, L., Cully, J. A., Loboprabhu, S. M., Lomax, J. W., \& Stanley, M. A. (2009). Integration of religion into cognitive-behavioral therapy for geriatric anxiety and depression. Journal of Psychiatric Practice, 15(2), 103-112.

Pearce, M., \& Koenig, H. G. (2013). Cognitive behavioural therapy for the treatment of depression in Christian patients with medical illness. Mental Health, Religion \& Culture, 16(7), 730-740.

Pearce, M. J., Koenig, H. G., Robins, C. J., Daher, N., Shaw, S. F., Nelson, B., ... \& King, M. B. (2016). Effects of religious versus conventional cognitive-behavioral therapy on gratitude in major depression and chronic medical illness: A randomized clinical trial. Journal of Spirituality in Mental Health, 18(2), 124-144.

Prest, L. A., \& Robinson, W. D. (2006). Systemic assessment and treatment of depression and anxiety in families: The BPSS model in practice. Journal of Systemic Therapies, 25(3), 4-24.

Quast, A. (2014). Yogerapy: An integrated yoga and cognitive-behavioral, family-based intervention for children with anxiety disorders in high achieving environments (Unpublished Doctoral dissertation). The Chicago School of Professional Psychology, ABD.

Rosmarin, D. H. (2010). A randomized controlled evaluation of a spiritually integrated cognitive behavioral intervention for sub-clinical anxiety among Jews, delivered via the internet (Unpublished Doctoral dissertation). Bowling Green State University, ABD. 
Rosmarin, D. H. (2018). Spirituality, religion and cognitive-behavioral therapy a guide for clinicians. New York: The Guilford Press.

Rosmarin, D. H., Auerbach, R. P., Bigda-Peyton, J. S., Björgvinsson, T., \& Levendusky, P. G. (2011). Integrating spirituality into cognitive behavioral therapy in an acute psychiatric setting: A pilot study. Journal of Cognitive Psychotherapy, 25(4), 287-303.

Rosmarin, D. H., Bocanegra, E. S., Hoffnung, G., \& Appel, M. (2019). Effectiveness of cognitive behavioral therapy for anxiety and depression among orthodox jews. Cognitive and Behavioral Practice, 1-12.

Shapiro, D., Cook, I. A., Davydov, D. M., Ottoviani, C., Leuchter, A. F., \& Abrams, M. (2007). Yoga as a complementary treatment of depression: Effects of traits and moods on treatment outcome. eCam Advance Access, 4, 493-502.

Smith, J. A., \& Smith, A. H. (2004). Treating Faith-Based Infertile Couples Using Cognitive-Behavioral Counseling Strategies: A Preliminary Investigation. Counseling and Values, 49(1), 48-63.

Sperry, L. (2012). Spirituality in clinical practice. New York: Routledge Taylor \& Francis Group.

Sperry, L., \& Shafranske, E. P. (2007). Spiritually oriented psychotherapy. ABD: American Psychological Association.

Stott, R., \& Salkovskis, P. (2010). Oxford guide to metaphors in CBT: Building cognitive bridges. Oxford, UK: Oxford University Press.

Sudak, D. M. (2006). Psychotherapy in clinical practice cognitive behavioral therapy for clinicans. Philadephia: Lippincott Williams \& Wilkins a Wolters Kluwer Business.

Tan, S. Y., \& Johnson, W. B. (2007). Spiritually oriented cognitive-behavioral therapy. In L. Sperry \& E. P. Shafranske (Eds.), Spiritually oriented psychotherapy (pp. 77-103). ABD: American Psychological Association.

Thygeson, M. V., Hocke, M. C., Clapsaddle, J., Robbins, A., \& Moquist, K. (2010). Peaceful play yoga: Serenity and balance for children with cancer and their parents. Journal of Pediatric Oncology Nursing, 27(5), 276-284.

Türkçapar, H. (2019). Bilişsel davranış̧̧ı terapi temel ilkeler ve uygulama. İstanbul: Epsilon Yayınevi.

Valente, V. G., \& Marotta, A. (2011). Prescribing yoga to supplement and support psychotherapy. In J. D. Aten, M. R. McMinn, \& E. L. Worthington (Eds.) Spiritually oriented interventions for counseling and psychotherapy. (pp. 251-276). Washington: American Psychological Association.

Vinod, S. D., Vinod, R. S., \& Khire, S. U. (1991). Evaluation of the effect of yoga on anxiety in youth in relation to anxiety-inducing areas of life. Yoga Mimamsa, 30, 25-30.

Wachholtz, A. B., \& Pargament, K. I. (2005). Is spirituality a critical ingredient of meditation?: Comparing the effects of spiritual meditation, secular meditation, and relaxation on spiritual, psychological, cardiac, and pain outcomes. Journal of Behavioral Medicine, 28(4), 369-384.

Walsh, F. (2009). Spiritual resources in family therapy. New York: The Guilford Press.

Weishaar, M E. (1993). Aaron T. Beck. London: Sage.

Wenzel, A., Dobson, K. S., \& Hays, P. A. (2016). Cognitive behovioral therapy techniques and strategies. Washington: American Psychological Association.

Williams Sr, M. A. (2012). Exploring the relationship between gratitude and family satisfaction among college students (Unpublished Doctoral dissertation). Ohio University, ABD.

Wright, L. M., Watson, W. L., \& Bell, J. M. (1996). Beliefs: The heart of healing in families and illness. New York: Basic Books. 